\title{
Gringo in Mañanaland: Latin America in Hollywood $^{1}$
}

Anelise R. Corseuil ${ }^{2}$

UFSC

\begin{abstract}
This article presents an analysis of Gringo in Mañanaland, a 1995 documentary by the American media activist and producer DeeDee Halleck. This documentary offers a revisionist perspective about the US representations of Latin America especially by Hollywood films. Thus, Halleck's production is representative of the reflexive aesthetics of contemporary documentary production. Such aesthetics is revealing of a fruitful political, economic and cultural debate, as an alternative to the commercial film production. As support for the discussion of Gringo in Mañanaland as a revisionist documentary, this analysis relies on the studies about Hollywood films and their representations of Latin America by Robert Burgoyne, Tunico Amancio and David Bordwell, as well as on Robert Rosenstone's studies on film as tools to revision of history.
\end{abstract}

Key-words: Documentary. Representation. Audiovisual theory.

\section{GRINGO IN MAÑANALAND: A AMÉRICA LATINA EM HOLLYWOOD}

Resumo: Este artigo apresenta uma análise de Gringo em Mañanaland, um documentário de 1995 de DeeDee Halleck. O documentário oferece uma perspectiva revisionista sobre as representações da América Latina, especialmente as construídas por filmes de Hollywood. Assim, a produção de Halleck é representativa da estética reflexiva da produção documental contemporânea. Tal estética é reveladora de um fecundo debate político, econômico e cultural, como alternativa à produção cinematográfica comercial. Para suporte à discussão de Gringo em Mañanaland como um documentário revisionista, esta análise se apoia nos estudos de Robert Burgoyne, Tunico Amancio e David Bordwell sobre narrativa e representação, bem como nos estudos de Robert Rosenstone sobre o cinema como ferramenta para revisão histórica.

Palavras-chave: Documentário. Representação. Teoria do audiovisual.

1 Parts of this article were first published in Portuguese as "Gringo in Mañanaland (Gringo na Terra de Mañana): Compilação de Imagens sobre a América Latina” In Corseuil, Anelise R. A América Latina no Cinema Contemporâneo: outros olhares. Florianópolis: Insular, 2012.

2 Possui graduação em Licenciatura em Letras/Inglês e Literatura pela Universidade Federal de Santa Catarina (1985); mestrado em Literaturas de Língua Inglesa, Eastern Michigan University (1987); doutorado em Literaturas em Língua Inglesa, Wayne State University (1992); e pós-doutorado no Departamento de Televisão, Teatro e Cinema da Universidade de Glasgow, 2000. É professora titular na Universidade Federal de Santa Catarina, Departamento de Língua e Literatura Estrangeiras desde 1993; Coordenadora do Curso de Pós-Graduação em Letras/Inglês. É Editora-Chefe da Revista Ilha do Desterro desde 1994 (UFSC); Editora-Chefe da Revista Brasileira de Estudos de Cinema e Audiovisual, REBECA (2011-2015), Editora Associada da Revista de estudos Anglo-Americanos 2011- . Coordenou o Projeto de Cooperação Internacional Interdisciplinaridade em Literatura e Cinema CAPES/FIPSE de 2002 a 2009. Foi Vice-Presidente da SOCINE (Sociedade Brasileira de Estudos de Cinema e Audiovisual) e da ABRAPUI, Associação Brasileira de Professores Universitários de Inglês. Atua nas seguintes áreas de ensino e pesquisa: teoria literária, estudos culturais, estudos de cinema (documentário, filme histórico e adaptação). É pesquisadora com bolsa de produtividade do CNPq. 


\section{Introduction}

I would like to thank Professor Neide Garcia Pinheiro for the invitation to contribute with an article to this special issue of Interfaces on the $50^{\text {th }}$ anniversary of Letras Course at UNICENTRO. In 2003, I had the opportunity to participate in the MINTER project between Curso de Pós-Graduação em Inglês Estudos Linguísticos e Literários at UFSC and Curso de Letras at UNICENTRO - a project developed in three years. One of the results of this collaboration, among many, was to advise graduate research work of faculty members of Curso de Letras at UNICENTRO in the area of Literatures in English and Linguistics. Here I mention the MA and $\mathrm{PhD}$ research work of Professor Pinheiro on Canadian documentaries, which I had the privilege to advise. Professor Pinheiro's project was partly associated with my own research interests on issues of representation, film studies and national identity.

The documentary here analyzed is DeeDee Halleck's Gringo in Mañanaland (1995), for which the American documentarian was awarded two Rockefeller Media Fellowships, and won a special jury prize at the Trieste Festival for Latin American Film. This documentary is one of the extensive lists of production by Halleck, who has been working in alternative media since the early 1970s. She is a pivotal figure in the development of open media, being the founder of Paper Tiger Television (PTTV). This radical television program and open media collective has influenced and supported grassroots media organizations. PTTV has engaged with critiques of mass culture, also known for being committed to an anti-commercialism agenda. As Laura Stein states:

Paper Tiger shows utilize political economy and critical cultural theory to critique media content and to call attention to the disjuncture between people's lived experiences and media representations. The goal is to create critical viewers with a sophisticated understanding of how and why artifacts of the culture industry adopt particular forms and functions. (2001, 14 , online).

Halleck's career as a media activist and producer has roots in her early adolescence when she moved to Cuba. In a video production for Dee Dee Halleck Visionary: artist, activist, video maker, educator, Halleck talks about that time, and describes the family life, the houses where they lived, and her mother's concerns with keeping their American culture alive. In the same video production, the filmmaker emphasizes that her family had better social and economic conditions than the Cubans. As she states: "(...) I felt that our position there was really wrong. And that we were living in a way that ... uh...took the life and the possibilities from the Cubans. And I always ... it really troubled me and made me want to be involved in trying to change that" (HALLECK, 2019, online). Therefore, living in Cuba also contributed to developing her awareness of the stereotypical images of Latin America created by popular media in the US. She recalls her experience of watching American films in Cuba.

(...) I always would wait for the New Yorker magazine and read especially the movie reviews (...) I would look at the cartoons and then, later, I would read the cinema reviews (...) then when I got to Cuba, I was like uh.... sort of it gave me an edge to criticize films and to look at films with a kind of a critical eye ... especially the films that were about Latin America... Here, I was sitting in this audience on a bench with workers surrounded by workers and workers' families and there the Weekend in Havana show. I remember seeing that and Havana ... it wasn't anything like what Cuba was like, the Cuba that I knew was like .....it was very very different (...) (HALLECK, 2019, online).

Halleck's documentary is representative of the reflexive aesthetics of contemporary documentary production. Such aesthetics is revealing of a fruitful political, economic, and 
cultural debate, as an alternative to the commercial film production. A number of contemporary documentaries and political films have challenged the unequal socioeconomic and cultural relations in a world that is increasingly interconnected and globalized. In parallel to the awareness of economic and cultural globalization processes, Gringo in Mananaland suggests the transnationalization of cinema, which can be seen as a two-way street, as aesthetics and narratives transit freely. The national allegory, as a political form generally associated to third-world countries, or the parody so frequently related to the postmodern cinema are not the privilege of one national cinema or of major technological world centers, but are present in the filmic production of different nations from various economic contexts. With the innumerous uses of parody in contemporary cultural production what one sees is a filmic production that is more aware of its own act of narrating, evoking the need for a revision of the many discourses reproduced in cinema.

Recent documentaries make room for other possible readings of the relation between the represented object and its forms of representation, revealing meta-discursive relations, which problematize the very forms of representation of the documentary. In her analysis of different documentaries, Bruzzi emphasizes, for instance, the irony in the narrative of The Atomic Cafe (1982), by Kevin Rafferty, Jayne Loader and Pierce Rafferty, and the questioning on the forms of compilation of the image in London (1992), by Patrick Keiller. In that context the new documentary, or what I am calling the postmodern documentary, is characterized by its questioning or rupture with the assumed objectivity and realism associated with the documentary, by means of a self-reflexive meta-narrative. The documentary brings up its complex relation with reality, since its "objective" search for the real has always been impossible.
The documentary "is predicated upon a dialectic relationship between aspiration and potential, that the text itself reveals the tensions between the documentary pursuit of the most authentic mode of factual representation and the impossibility of this aim" (BRUZZI, 2000, p.4). For Bruzzi, documentary makers and theoreticians like John Grierson and the Soviets, more specifically Dziga Vertov, have already anticipated the fissure between the real and representation in the documentary: Vertov introduced a reflexive cinema, aware of its intervention on the real, while Grierson called attention to the element of dramatization in the documentary (BRUZZI, 2000, p.5), as the only non-fictional genre capable of resorting to dramatization.

The majority of the critical theories about the documentary show the problems of a genre that oscillates between the real and the fictional. In spite of the narrative differences between one genre and another, the documentary always brings narrative elements that make it impossible to match the factual, as there are marks of the subjectivity from the narrator (voice over), dramatization (the performative act) by the interviewee, and/or the selection of images and material by the editor, with subjective and hypothetical choices about the represented object. Such elements, among others, become more evident in postmodern documentaries, since these films both show and challenge the presupposed invisibility associated to the documentary, that is, its alleged ability of the documentary to represent the real without the mediation of a discourse of its own, built or planned by a subject. In that sense, the postmodern documentary makes explicit the process of building meanings by means of selecting, organizing, and representing historical facts and characters; thus, making evident the interpretive mark by different documentary makers, who decide what specific historical significants will be included or left out 
of the film, so that the assemblage of images or the text at issue will build a meaning of its own (WHITE, p. 26-47). Documentaries can also be seen as representations bearing a specific ideology through which ethnicities and nationalities are represented. In the same way, images, narratives, and stereotypes related to certain ethnicities and nationalities influence the collective imaginary of a more globalized world population.

Recent documentaries also resort to different narratives, building plots more objective and/or more critical of their own discourse. As I have argued elsewhere, in spite of the differences established between one genre and the other, fictional or historical, narrative theory, as foregrounded by Hayden White, equates the historical discourse with the fictional, and makes possible for one to draw a parallel between the fictional historical film and the documentary with history, since non-fictional narratives are also concerned with the production of meaning. ${ }^{3}$ For White, annals, chronicles and historical narratives have a tendency to moralize History, while organizing diverse materials and focusing on specific historical characters that award coherence to a number of arguments. Thus the interpretive mark by different historians, or by extension, by film directors, shall, in that way, define the inclusion or exclusion of any specific historical significant in order to allow the set of images or texts to build a specific meaning. ${ }^{4}$

Given that, Halleck's documentary is an example of how the production of documentaries

\footnotetext{
3 See Corseuil, Anelise R. A América Latina no Cinema Contemporâneo: outros olhares. Florianópolis: Insular, 2012 (pp.16-17).
}

4 "Common opinion has it that the plot of a narrative imposes a meaning on the events that make up its story level by revealing at the end a structure that was immanent in the events all along. What I am trying to establish is the nature of this immanence in any narrative account of real events that are offered as the proper content of historical discourse... The authority of the historical narrative is the authority of reality itself; the historical account endows this reality with a form and thereby makes it desirable by the imposition upon its process of the formal coherency that only stories possess." (WHITE, 1973, p. 20). and political films invites one to rethink the influence of the film industry on a collective imaginary by means of the films' circulation of narratives, aesthetics, icons and images associated to Latin America in an international arena. The parodic reading of discourses, narrative forms, and of a historical past also places us in the present, since it situates us in a new place in the discourse, which foregrounds a critical view of history. Such a process of revision and rereading of narratives and stereotypes is explored in Gringo in Mañanaland, as it presents a parodic reading of US and Hollywood films on Latin America produced since the beginning of the twentieth century.

\section{Development}

Halleck's documentary reveals the Hollywood industry's consistent processes of hegemony, neocolonialism and exclusion in relation to Latin-American culture (Figure 4). Gringo in Mañanaland presents a careful compilation of images from a number of films made in the USA about Latin America, including scenes from silent movies, industrial cinema, home videos, American governmental propaganda, ethnographical documentaries produced for television since the beginning of the twentieth century, and Hollywood fictional films produced since the 1920s through the end of the 1950s.

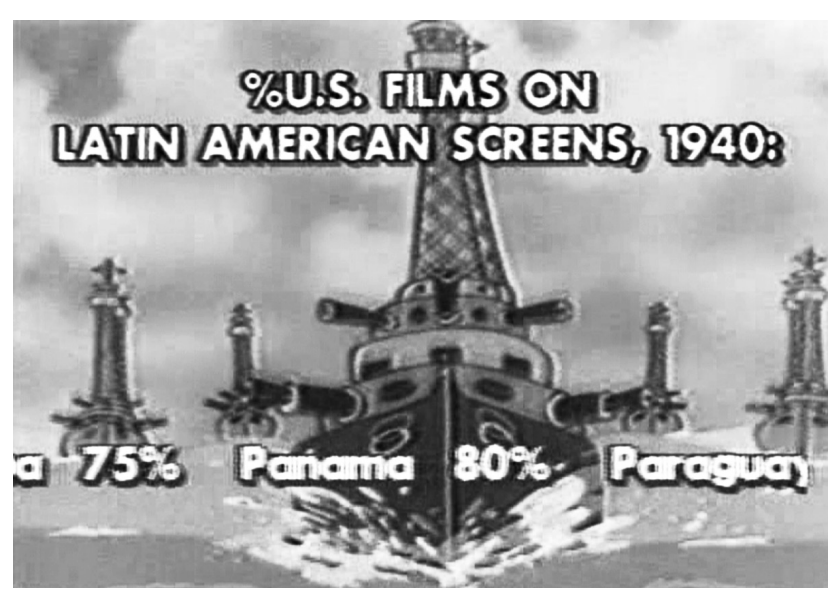

Figure 1: Source - Gringo in Mañanaland, by DeeDee Halleck (1995). Courtesy by DeeDee Halleck. 
Halleck presents a panorama of many films produced in the USA about Latin America, or which have Latin America as its setting. Halleck creates a parodic montage of juxtaposed images of Latin America, thus, ironically exposing the Manichaeism associated with the alleged invisibility of the narrative of the American cinema, also revealing of the propagandistic and ideological aspects in these films, as they represent Latin America and its cultural elements with stereotypes. Contrary to what could be defined simply as a denunciatory documentary, Halleck's parodical language (which is based on the ironic reading of the images appropriated by the films) deconstructs meanings and problematizes the political and cultural relations between Latin America and the USA.

The structure of Gringo in Manañaland is based on segments constituted by parts of many different American films produced along the 20th century. Each filmic sequence collected from these older movies is presented in Gringo in Mañanaland with a subtitle as it gathers images from a thematic nucleus: "Arrival" presents film sequences from older movies which show the arrival of the "gringos" in Latin-American countries; "The Past" shows film images in which the US intervened in LatinAmerican historical past; "Paradise" presents Latin America seen by Hollywood and the Americans as a land of opportunities, a sort of virgin land, which includes the gentleness and sensuality of Latin women; "Ambition" shows films from Hollywood in which American expansionism is well applied in Latin-American countries; "Problem \#1" shows film sequences from older movies revealing of the inadequacy of American women in Latin America; "Problem \#2" is about the rebellions and the ruffianism associated to native men; "Technology" shows the use of force to pacify the revolutionaries; "Cooperation", the counterrevolutionary forces coopted by the USA to bring order back; and "Partners", the Good Neighbor Policy to keep the desired order. The sequences of the films are distributed within each segment of Gringo in Mañanaland to reveal the ideological content of the narratives, thus, neutralizing their power to deceive, as their images are presented out of the original context.

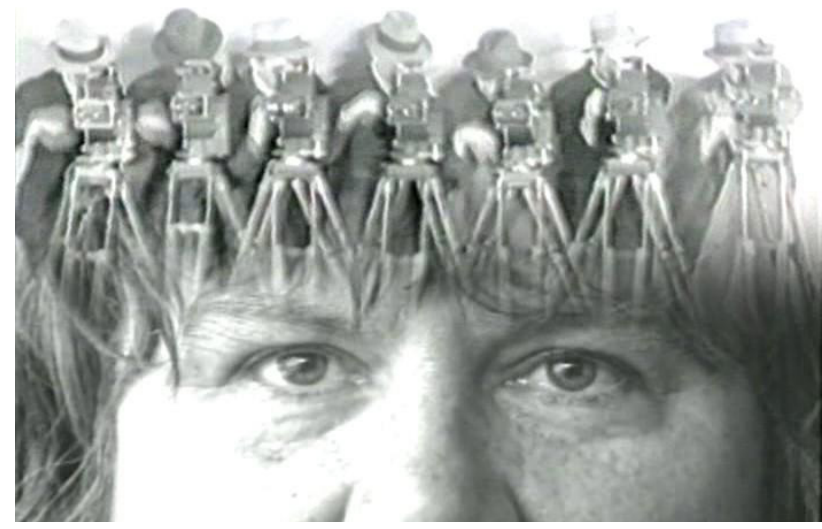

Figure 2: Source - Gringo in Mañanaland, by DeeDee Halleck (1995). Courtesy by DeeDee Halleck.

The introductory segment shows us the title of the film, Gringo in Mañaland. It is presented with the superimposition of images of cameras on tripods projected over Halleck's head, while she says that the images of Cuba seen in the movies have nothing to do with the country in which she lived when she was 12 years old, when her father worked there (Figure 2). From there, we are presented with images from Pathé Office (1920), Down Mexico Way (1941), sequences from various films produced by the United Fruit Company (1924), and from Yolanda and the Thief (1945). Since the beginning of the film, the spectator is faced with a mosaic of self-reflexive images about making movies, in which Halleck comments in voice-over what is the object of her film. Such voice-over is presented to the audience with superimposed images from old films, camera tripods and stock footage. The act owf appropriation and deconstruction of the original meaning of films like Down Mexico Way and Yolanda and the Thief allows the spectator to adopt a critical view of the commercial interests involved 
with cinema. In the case of Yolanda and the Thief, the dialogue between Fred Astaire's character and his partner reveals their purely commercial interests in some country called Patria.

Furthermore, the sequence reinforces the economic interests of the United Fruit Company in developing its farms in Central America at the time. The film, thus, allows a double reading: the understanding of the capitalist expansion through multinational companies in third-world countries as a kind of neo-colonial practice in the twentieth century, and the expansion of the Hollywood industry in Latin-American countries, which is an issue hidden behind the romanticism and moralism of Hollywood narratives. The appropriation of images in DeeDee Halleck's film invites one to think about such neocolonial commercial and cultural practices, as it denounces the teleological elements in these films, in which the American protagonist always brings order to a Latin American country. The moral ending also functions to refrain Hollywood excesses. Such a moral can be further observed in the developmental ideology of multinational companies, such as United Fruits, as they arrive in countries that are shown in the movies as always in need to be developed. Ironically, the appropriation of images in Gringo in Mañanaland is possible due to the international circulation of images from the cinematographic industry, and by means of the easy access to films through more democratic media, among which one can include the video.

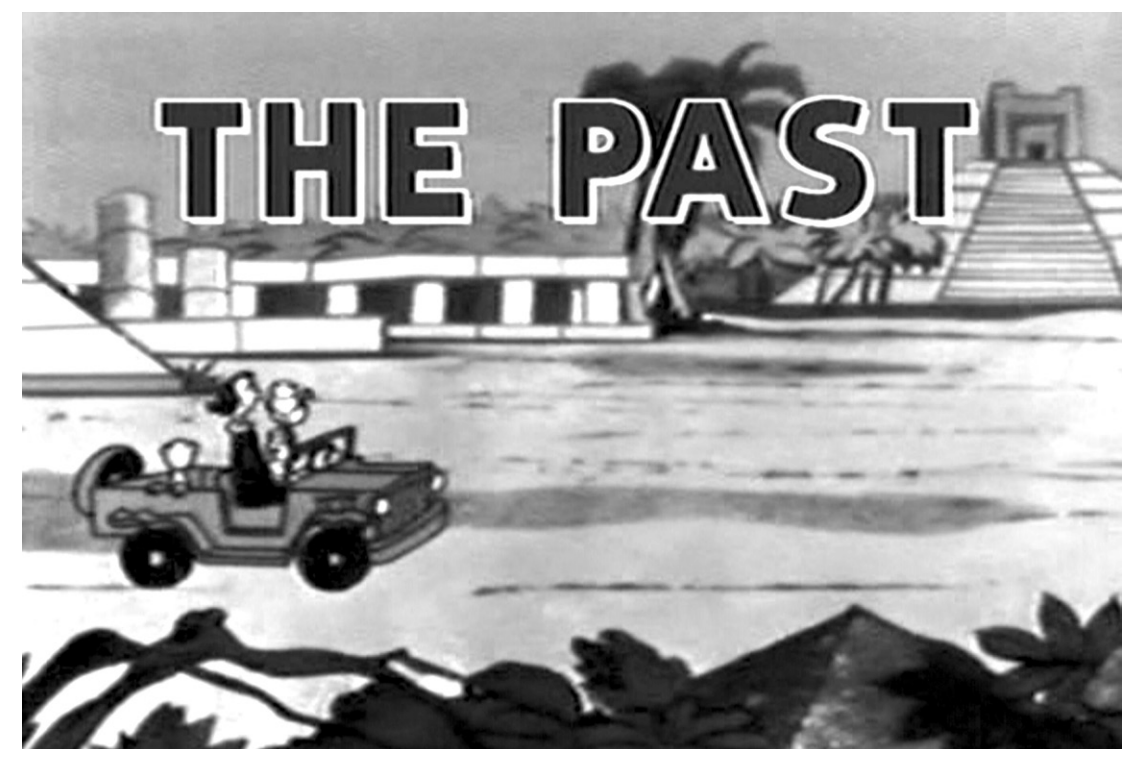

Figure 3: Source - Gringo in Mañanaland, by DeeDee Halleck (1995). Courtesy by DeeDee Halleck.

The rereading as well as the critical revision of the stereotypes associated with Latin America are reinforced in the segment entitled "The Past" (Figure 3), in which images of (1) a Popeye cartoon, (2) a documentary titled Carnegie Expedition (1930), and (3) images from Down Argentine Way (1940) are juxtaposed. The segment of Popeye exposes the lack of knowledge in relation to the Aztec civilization, as the character claims that the "ruins must have been caused by the poverty of the comrades" that lived there. Olive Oyl smiles and corrects him, saying that the ruins were caused by time. In the documentary Carnegie Expedition, an American researcher using boots and khaki clothes explains that the ruins of a Mayan pyramid in Mexico are being excavated by Americans, through an agreement with the Mexican 
government. The position of the camera and the discourse by the researcher/anthropologist reinforce the importance of the USA intervention, necessary for the Mexican past to be "rediscovered."

As Gringo in Mananaland decontextualizes the sequences of the selected films it shows, it presents two forms of making those films unfamiliar: (1) by the repetition of gestures, dialogues and actions in each of the selected sequences, Halleck's documentary resignifies the process of hegemony of the United States as some kind of saturated image; (2) by the juxtaposition of contradictory images, which are revealing of the paradoxes among the many discourses in the film. In the case of the repetition of images, gestures and actions certain meanings are repeated over and over in a way that the spectator can perceive the saturation of certain discourses. One of these meanings is the image of the Latin woman as sensual and naive. The segment called "Paradise" (Figure 4) presents a collage of sequences from different films in which Latin women are constituted by their sensuality and naivete. In the first sequence of Carnival in Costa Rica (1947), a priest mounting a mule greets beautiful women picking coffee in a plantation. Well-dressed women in a typical Hollywood setting sublimate any notion of work, although it is a coffee plantation. To that sequence an image from another film (Cookoo Cavaliers, 1940) is juxtaposed in which four misses with seductive looks are introduced in medium shot: Jauntier, Conchita, Pepita and Rosita. In this way, Halleck's documentary functions as a rereading of the many films that compose hegemonic and stereotypical views of Latin America -- films with images that are repeated over and over acquiring a life of their own, whose narratives construct a collective imaginary of Latin America.

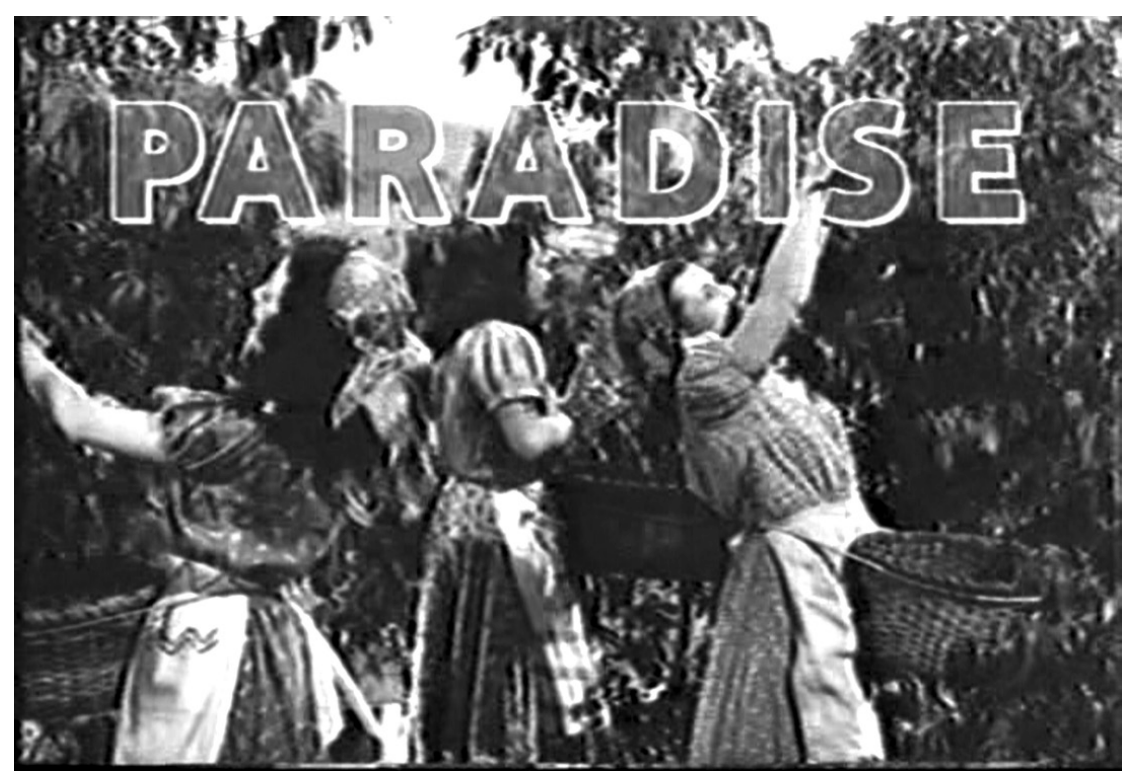

Figure 4: Source - Gringo in Mañanaland, by DeeDee Halleck (1995). Courtesy by DeeDee Halleck.

Contrastive with the collage of film segments which convey similar ideas about Latin America, Halleck also elaborates a critique of the exploitation of Latin America by the USA in her handling of starkly contrastive sequences from older movies. The juxtaposition of a TV film about the Pan American conference in Washington in 1930 with the sequence of Carmen Miranda in The Gang's all Here (1943) makes evident the American policy of establishing a good-will pact with its neighbors moved by political and commercial interest. The image of Carmen Miranda with her hats, bananas and with all the excess of the spectacle, and which is associated with Latin America as a land of richness, shows to the spectator the real economic interest behind the diplomatic meetings between presidents and secretaries 
of State from many nations involved in the long process of Pan-Americanism.

The long sequence of images in segment "Problem \#1" of Gringo in Mañanaland puts side by side images of Cuban women working in sugarcane plantations and glamorous sequences from the film Weekend in Havana (1941), in which Hollywood stars have fun in a casino in Havana. The unbalance between an economy of excess -- the Hollywood economy -- and that of scarcity, which is represented by the working women, invites one to recontextualize the images juxtaposed by Halleck's film. Thus, the films, as they are emptied out of their supposed naturalism (the alleged neutral realism of the documentary, and the narrative invisibility in the classical cinema), ${ }^{5}$ they are deconstructed: what becomes revealed by Halleck's film is the historical hegemonic system imposed on the Cubans through American show business and by means of a neocolonialist economy of rural exploitation.

Mañanaland can be read as a parody of Bananaland, which embodies two significant meanings: land of plenty, in which one can produce without much labor; and a land with no order, thus justifying the foreign intervention. "Banana Republic" is a small republic without order. Mañanaland is the land of tomorrow; that land which has not matured yet, and that is the reason for its need to be guided, oriented by a foreigner, the gringo. The term, Mañanaland, also suggests that all Latin-American countries can be seen in the same way, without differences, Thus the stereotypes are repeated endlessly: Mexicans become Brazilians, who become Argentinians. The title, Gringo in Mañanaland, however, is more than just ironic about such a view, since it presents the "gringo" as the foreigner, the naïve, the North-American - the one who is incapable of understanding the differences.

5 See BORDWELL, David. Classical Narration: the Hollywood Example.

Narration in the fiction film. The University of Wisconsin Press, 1985.
The gringo is thus an ironic reference: he is a foreigner unable to recognize the other. In fact, the final scene of the film, after the final credits, can be read as an authorial commentary: subtitles from an old film show a dialogue in which a Mexican tells an American: "Yesterday you were my good friend; today you are just my friend; tomorrow..."

And tomorrow is indicated by the puff of the Mexican's cigar on the face of the gringo/ American. The American does not answer, and the future is a point of interrogation. Within this context, the stereotype of Latin Americans in Hollywood filmography (and within the collective imaginary of Americans) reveals the need to repeat an image, an idea, a concept of something that cannot be named, thus domesticating the other, the Latin American.

\section{Conclusion}

The careful compilation of images in Gringo in Mañanaland is a critique of cinema as a narrative form capable of perpetuating images, creating icons and stereotypes, as well as on its associations with expansionist and neo-colonialist discourses in the USA. The parodic narrative of Gringo in Mañanaland challenges those discourses linked to the formation of a Latin identity; it shows that cultural identities are in a constant process of formation, and that it happens at the margins and at the center of hegemonic cultures, at the same time, the film displaces and makes a parody of the Anglo-American discourses under making. DeeDee Halleck is also in the center and at the margins of American culture, as she is capable of deconstructing hierarchical positions and binarism. The director experienced Cuba and the US in different ways, being hybrid and multicultural, she can speak from the inside and outside about the inter-relations between the USA and Latin America. Thus, her initial testimony cannot be seen only as 
a figure of rhetoric, but as one which constitutes itself into a political and self-aware discourse, as a discourse that has the power to change views and places of hierarchy in the discourse.

The film here analyzed shows a new and critical political view of the film industry in its relation to Latin America as well as to its historical relation to the USA. I have tried to map the conscious perception of DeeDee Halleck. With the production of documentaries such as Gringo in Mañanaland, there is the construct of more subjective and self-reflexive documentaries. In that sense, the film redefines a place for those who make these representations as well as it calls attention to the need to review old discursive and political practices of representation.

\section{References}

AMANCIO, Tunico. O Brasil dos Gringos: Imagens no Cinema. Niterói: Intertexto, 2000.

BRUZZI, Stella. New Documentary: A Critical Introduction. London and New York: Routledge, 2000 .

BURGOYNE, Robert, Film Nation: Hollywood Looks at U.S. History. Minneapolis: University of Minnesota. 1997.

BORDWELL, David. Classical Narration: the Hollywood Example. Narration in the fiction film. The University of Wisconsin Press, 1985.

CORSEUIL, Anelise R. A América Latina no Cinema Contemporâneo: outros olhares. Florianópolis: Insular, 2012.

EXPERIMENTAL TV CENTER. Dee Dee Halleck. http://www.experimentaltvcenter.org/ deedee-halleck. Acesso em 04/11/2020.

HALLECK, D.D. Dee Dee Halleck visionary: artist, activist, video maker, educator. 2019. http:// deedeehalleck.com/ acesso em 04/11/2020.
PAPER TIGER TELEVISION. https:// papertiger.org/get-involved/links-resources. $04 / 11 / 2020$

ROSENSTONE, Robert A. (Org.). Revisioning history: film and the construction of a new past. (Princeton Studies in Culture/Power/History). Princeton: Princeton University press, 1995. http:/ / www.experimentaltvcenter.org/deedee-halleck

STEIN, Laura. Access Television and Grassroots Political Communication in the United States. In: J. Downing (with Ford, T.V., Gill, G. and Stein, L.), Radical Media: Rebellious Communication and Social Movements. California: Sage Publications, pp. 299-324 https://moody.utexas.edu/sites/ default/files/stein_3.pdf. 30/10/2020.

Filmography

Gringo in Mañanaland (1995). Director: DeeDee Halleck; production: Dee-Dee Halleck Productions.

Submissão: novembro de 2020 . Aceite: dezembro de 2020 . 